\title{
Stem Cell Research \& Therapy marks its first anniversary
}

\author{
Philippa Locke ${ }^{1 *}$, Timothy O'Brien² and Rocky S Tuan ${ }^{3}$
}

Just over a year ago we launched Stem Cell Research $\mathcal{E}$ Therapy with the aim of it becoming the major forum for translational research into stem cell therapies [1]. As we celebrate our first year of publication we look back at what we have achieved and how we hope to progress in our second year and beyond.

Stem Cell Research $\mathcal{E}$ Therapy is an international, peerreviewed, open access journal with a special emphasis on basic, translational, and clinical research into stem cell therapeutics, including animal models, and clinical trials. At launch we noted both the enormous potential of stem cell therapies and the major hurdles that have to be overcome [1]. While the past year has seen continued legal turmoil regarding governement funding of embryonic stem cell research in the USA [2], stem cell research continues to progress apace internationally.

\section{Open access to research}

In a fast-moving world the importance of research results being disseminated as quickly and widely as possible cannot be underestimated. All research articles published in Stem Cell Research $\mathcal{E}$ Therapy are open access; they are freely available online from the moment of publication and universally accessible regardless of location, affiliation or ability to pay. Articles are archived in a number of open access repositories to ensure their permanent availability, including PubMed Central [3]. Wider distribution of their work is possible as authors retain the copyright of their article while allowing others to use and reproduce it with correct attribution. Open access publishing means research is much more visible both within the academic community and the wider population, and some studies have suggested that this increased availability may lead to an open access article being more likely to be cited [4].

Online publication allows us to measure the number of times an article has been accessed via the journal website.

*Correspondence: editorial@stemcellres.com

'BioMed Central, Floor 6, 236 Gray's Inn Road, London, WC1X 8HB, UK Full list of author information is available at the end of the article
As research articles are open access and available via other sources, such as PubMed Central, overall accesses will be considerably higher, however these figures are highly encouraging and indicate that our articles are being well-accessed. At the time of writing our mostaccessed research article is from Mohan Vemuri and colleagues, describing a novel serum-free mesenchymal stem cell culture medium which could substitute illdefined traditional culture medium for research applications [5]. This article has been accessed more than 8000 times via the journal website alone since its publication last year. Also featuring in our most-viewed articles are an article from Songtao Shi's group demonstrating that transplanted stem cells from human exfoliated deciduous teeth can be used to treat systemic lupus erythematosus in a mouse model [6], and an evaluation of electroporation as a suitable method for reliable, efficient transfection of human embryonic stem cells from the group of Ronald Hart [7].

\section{Informed and incisive commissioned content}

In addition to open access research, Stem Cell Research $\mathcal{E}$ Therapy publishes commissioned content including comprehensive reviews of recent advances written by experts in the field, and speculative, opinionated commentaries. Our most-accessed article so far is a review by Danièle Noël and colleagues discussing the targets and mechanisms of mesenchymal stem cell-mediated immunosuppression, and their potential use in a variety of autoimmune diseases [8]. As well as stand-alone review articles, we also publish review series consisting of concise articles covering one aspect of a broader theme. A collection of articles on 'Stem cell niche' features a review from Gilbert and Blau on how combining stem cell biology and creative bioengineering technology could expand our understanding of regulation of the stem cell niche [9], and Sommer and Mostoslavsky summarized current reprogramming methodologies as part of our series on 'Induced pluripotent stem cells' [10]. We have recently published the first article [11] in our series on 'Immunology and stem cells', edited by Christian Jorgensen, and look forward to sharing with our readers the upcoming reviews in this series. 


\section{Looking ahead}

It has been an exciting and productive first year for the journal and we would like to thank our Editorial Board, authors, reviewers and readers for their invaluable support. As ever we welcome your ideas, comments and suggestions on what the journal has, should, or could publish. Stem Cell Research \& Therapy has built a strong foundation and we look forward to its continued growth and recognition as a valued forum for the global stem cell research community.

\section{Competing interests}

$\mathrm{PL}$ is an employee of BioMed Central and receives a fixed salary. TO and RT are the Editors-in-Chief of Stem Cell Research \& Therapy and receive an annual honorarium.

\section{Author details}

'BioMed Central, Floor 6, 236 Gray's Inn Road, London, WC1X 8HB, UK. ${ }^{2}$ REMEDI - National Centre for Biomedical Engineering Science, National University of Ireland, Galway, Ireland. ${ }^{3} U$ niversity of Pittsburgh School of Medicine and University of Pittsburgh Medical Center, 450 Technology Drive, Suite 300, Pittsburgh, PA315219-3110, USA.

Published: 6 May 2011

\section{References}

1. Donnelly A, Johar S, O'Brien T, Tuan RS: Welcome to Stem Cell Research \& Therapy. Stem Cell Res Ther 2010, 1:1.
2. NIH Stem Cell Information Home Page. [http://stemcells.nih.gov/]

3. PubMed Central. [http://www.ncbi.nlm.nih.gov/pmc/]

4. Hitchcock, S: The effect of open access and downloads ('hits') on citation impact: a bibliography of studies. The Open Citation Project. [http://opcit. eprints.org/oacitation-biblio.html]

5. Chase LG, Lakshmipathy U, Solchaga LA, Rao MS, Vemuri MC: A novel serumfree medium for the expansion of human mesenchymal stem cells. Stem Cell Res Ther 2010, 1:8.

6. Yamaza T, Kentaro A, Chen C, Liu Y, Shi Y, Gronthos S, Wang S, Shi S: Immunomodulatory properties of stem cells from human exfoliated deciduous teeth. Stem Cell Res Ther 2010, 1:5.

7. Moore JC, Atze K, Yeung PL, Toro-Ramos AJ, Camarillo C, Thompson K, Ricupero CL, Brenneman MA, Cohen RI, Hart RP: Efficient, high-throughput transfection of human embryonic stem cells. Stem Cell Res Ther 2010, 1:23.

8. Ghannam S, Bouffi C, Djouad F, Jorgensen C, Noël D: Immunosuppression by mesenchymal stem cells: mechanisms and clinical applications. Stem Cell Res Ther 2010, 1:2

9. Gilbert PM, Blau HM: Engineering a stem cell house into a home. Stem Cell Res Ther 2011, 2:3.

10. Sommer CA, Mostoslavsky G: Experimental approaches for the generation of induced pluripotent stem cells. Stem Cell Res Ther 2010, 1:26.

11. Maumus M, Guérit D, Toupet $K$, Jorgensen C, Noël D: Mesenchymal stem cell-based therapies in regenerative medicine: applications in rheumatology. Stem Cell Res Ther 2011, 2:14.

doi:10.1186/scrt63

Cite this article as: Locke P, et al: Stem Cell Research \& Therapy marks its first anniversary. Stem Cell Research \& Therapy 2011, 2:22. 